\title{
Effects of ghrelin supplementation on the acute phase of Chagas disease in rats
}

\author{
Ferdinando de Paula Silva ${ }^{1 \dagger}$, Cássia Mariana Bronzon da Costa $^{1+}{ }^{1}$, Luiz Miguel Pereira ${ }^{1}$, \\ Diego Fernando Silva Lessa', Dimitrius Leonardo Pitol ${ }^{2}$, João Paulo Mardegan Issa², \\ José Clóvis do Prado Júnior ${ }^{1}$ and Ana Amélia Carraro Abrahão ${ }^{1 *}$
}

\begin{abstract}
Background: Trypanosoma cruzi is the causative agent of Chagas disease, which is endemic to subtropical and tropical Americas. The disease treatment remains partially ineffective, involving therapies directed to the parasite as well as palliative strategies for the clinical manifestations. Therefore, novel candidates for disease control are necessary. Additionally, strategies based on parasite inhibition via specific targets and application of compounds which improve the immune response against the disease is welcomed. Ghrelin is a peptide hormone pointed as a substance with important cardioprotective, vasodilatory, anti-apoptotic, anti-oxidative and immune modulatory functions. The aims of this study were to evaluate the immunomodulatory effects of ghrelin in male Wistar rats infected with the $Y$ strain of T. cruzi.
\end{abstract}

Methods: In order to delineate an immune response against T. cruzi mediated by ghrelin, we evaluated the following parameters: quantification of blood and cardiac parasites; analysis of cell markers (CD3 ${ }^{+}, \mathrm{CD}^{+}{ }^{+}, \mathrm{NK}, \mathrm{NKT}, \mathrm{CD} 45 \mathrm{RA}^{+}$, macrophage and $\mathrm{RT} \mathrm{B}^{+}$); nitric oxide (NO) production; lymphoproliferation assays; splenocyte apoptosis; and INF- $\gamma$, IL-12 and IL-6 quantification in sera.

Results: The animals infected with T. cruzi and supplemented with ghrelin demonstrated an upregulated pattern in macrophage and NO production, whereas an anti-inflammatory response was observed in T cells and cytokines. The low response against T. cruzi mediated by T cells probably contributed to a higher colonization of the cardiac tissue, when compared to infected groups. On the other side, the peptide decreased the inflammatory infiltration in cardiac tissue infected with T. cruzi.

Conclusions: Ghrelin demonstrated a dual function in animals infected with T. cruzi. Further studies, especially related to the decrease of cardiac tissue inflammation, are needed in order to determine the advantages of ghrelin supplementation in Chagas disease, mostly for populations from endemic areas.

Keywords: Chagas disease, Ghrelin, Immune response, Inflammation

\section{Background}

Chagas disease is a tropical neglected disease caused by Trypanosoma cruzi. The disease has an important socioeconomic impact in Latin America, afflicting about 6-8

*Correspondence: acarraro@fcfrp.usp.br

${ }^{\dagger}$ Ferdinando de Paula Silva and Cássia Mariana Bronzon da Costa contributed equally to this work

${ }^{1}$ Department of Clinical Analyses, Toxicology and Food Science, School of Pharmaceutical Sciences of Ribeirão Preto, University of São Paulo, Ribeirão Preto 14040-903, Brazil

Full list of author information is available at the end of the article million people whereas 65 million are under infection risk in endemic areas [1]. Due to the migration dynamics, the disease has been spread to non-endemic areas, such as North America, Europe, Japan and Australia [2]. In endemic areas, the disease is mostly transmitted by the contact with feces of infected triatomine insects after a bite or food contamination. Congenital transmission (including breastfeeding), blood transfusion organ transplantation and laboratory accidents are also important, particularly in non-endemic areas. Clinically, Chagas disease is divided into acute and chronic phases. The first 
is usually characterized by the absence or non-specific symptoms, evolving to an indeterminate form, which affects most of the infected patients. Some indeterminate patients develop the chronic phase, marked by cardiac (arrhythmia, heart-muscle disorder and heart failure) and/or digestive (enlargement of the oesophagus and the colon) disturbances [1].

Despite the efforts to develop new drugs and preventive approaches [3-6], there are only two available drugs (benznidazole and nifurtimox), which demonstrate sideeffects and a limited anti-T. cruzi action [7]. Thus, novel forms to control the disease are welcomed. One of the control strategies is based on the administration of molecules related to immune modulation, which contributes to an effective response against the parasite or avoid the deleterious symptoms of the chronic phase. Ghrelin is a hormonal peptide produced in ghrelinergic cells in the gastrointestinal tract and performs an important role in the regulation of appetite and metabolism $[8,9]$. The peptide stimulates the AMP-activated protein kinase (AMPK) in the hypothalamus, improving the glucose uptake, the fatty acid oxidation, glycolysis, whereas inhibits the fatty acid and glycogen synthesis and gluconeogenesis $[10,11]$.

Ghrelin also controls several immune functions, controlling inflammation and auto-immunity [12]. The mechanism of ghrelin immune regulation is based on the inhibition of the leptin and immune stimuli-induced proinflammatory cytokine production in T cells and monocytes, such as IL-1 beta, IL- 6 and TNF-alpha [13]. Thus, the anti-inflammatory effects of ghrelin are observed in autoimmune encephalomyelitis [14], arthritis [15], sepsis [16], hepatic inflammation [17], colitis/inflammatory bowel disease [18], pancreatitis [19], gastritis [20], lung injury [21], myocardial infarction [22] and intestinal ischemia-reperfusion [23]. However, there are few studies for the use of ghrelin against infectious agents [20,24]. Moreover, no studies have been performed in $T$. cruzi models, despite the potential of ghrelin for inflammation control. Therefore, there is a demand for the use of ghrelin in Chagas disease, which may contribute to alleviate the symptoms related to inflammation/auto-immunity, particularly cardiac lesion. Thus, our goal was to evaluate the immune effects of ghrelin administration during the acute phase of Chagas disease. The key points of the innate immune and adaptive responses, such as quantification of macrophages, NK/NKT cells, NO quantification, $\mathrm{CD}^{+} / \mathrm{CD}^{+}$cells, $\mathrm{T}$ cell proliferation and apoptosis were evaluated. We also quantified the levels of cytokines (INF- $\gamma$, IL12 and IL-6) in serum, for a complete description of the anti-inflammatory response induced by ghrelin. Using these parameters, the positive and negative effects of ghrelin in animals infected with $T$. cruzi were determined and will base further strategies to describe the mechanisms related to Chagas disease pathogenesis/ control.

The parameters from the acute phase are the first step to determine the potential of ghrelin as an immunomodulation agent for the control of Chagas disease symptoms. The anti-inflammatory pattern observed in the acute phase indicates the use of ghrelin for the chronic phase of Chagas disease, which probably contributes to reducing the intense cellular response and cardiac lesions [25]. Therefore, ghrelin has a potential to improve the immune response and alleviate the symptoms of Chagas disease, which will base a rational form to administrate this peptide to populations in endemic areas.

\section{Methods}

\section{Animals, experimental infection and treatment}

Male Wistar rats (90-100 g) were acquired from Facility House of the University Campus of Ribeirão Preto and housed two to a cage with water and feed ad libitum. Animals (6 per group) were randomized in the following groups: non-infected/non-treated control (C); noninfected/ghrelin treated control (CG); T. cruzi infected/ non-treated group (I); and T. cruzi infected/ghrelin treated group (IG). Infected groups were intraperitoneally inoculated with $1 \times 10^{5}$ blood trypomastigotes of the $T$. cruzi Y strain [26, 27], previously maintained by serial passage in Swiss mice. The ghrelin treatment was initiated $24 \mathrm{~h}$ after infection and performed for 14 days (single dose/day). We adopted a well-designed regimen of treatment, based on cardioprotective and anti-inflammatory studies performed in the rat model [28-33], which use ghrelin $100 \mu \mathrm{g} / \mathrm{kg}$ once or twice a day. Thus, ghrelin (R\&D Systems, Tocris, USA) was diluted in saline and $100 \mu \mathrm{g} / \mathrm{kg} /$ day was administered via subcutaneous injection. On day 15 post-infection, the animals were anesthetized with isoflurane (2.5\%) and euthanized by cervical dislocation. Spleens, peritoneal exudates and sera were collected for immune response evaluation and hearts were processed for histologic analysis.

\section{Parasitemia and animal weighing}

Parasitemia was determined on day 8 post-infection using Brener's method [34]. The animals were weighed on day 14 day post-infection using an electronic balance (Mettler-Toledo, Brazil).

\section{Peritoneal cells and oxide nitric}

The peritoneal cells were collected and processed as described in [35]. Briefly, the cells were suspended in RPMI (Merck KGaA, Darmstadt, Germany) supplemented with fetal bovine serum (10\%) and centrifuged at $1800 \times g$, for $5 \mathrm{~min}$ at $4{ }^{\circ} \mathrm{C}$. The pellets were suspended 
in ACK buffer $\left(0.15 \mathrm{M} \mathrm{NH}_{4} \mathrm{Cl}, 1 \mathrm{mM} \mathrm{KHCO}{ }_{3}, 0.1 \mathrm{mM}\right.$ NaEDTA), incubated for $2 \mathrm{~min}$ at room temperature and centrifuged $\left(1800 \times g\right.$ for $5 \mathrm{~min}$ at $\left.4{ }^{\circ} \mathrm{C}\right)$. The cells were suspended in RPMI and counted in a hemocytometer. The cell suspension was assessed for nitric oxide quantification and analysed by flow cytometry. For nitric oxide quantification [36], cells $\left(100 \mu \mathrm{l}, 2 \times 10^{5}\right.$ cells/well) were distributed in 96-well plates (Corning) and incubated with $1 \mu \mathrm{g} /$ $\mathrm{ml}$ lipopolysaccharide (LPS, catalogue number: L2654. Sigma-Aldrich, Darmstadt, Germany) for $48 \mathrm{~h}, 37{ }^{\circ} \mathrm{C}$, $5 \% \mathrm{CO}_{2}$. After incubation, the cells were centrifuged at $1500 \times g$, for $4 \mathrm{~min}, 20^{\circ} \mathrm{C}$ and $100 \mu \mathrm{l}$ of the supernatant transferred to a new 96 -well plate. The samples were incubated with $100 \mu \mathrm{l}$ Griess solution (1\% sulfanilamide, 0.1\% $\mathrm{N}-1$-Naphthyl ethylenediamine in $5 \%$ phosphoric acid) for $15 \mathrm{~min}$ at room temperature. The plates were read at $540 \mathrm{~nm}$ in an ELISA reader (Synergy H1, Biotek, Winooski, VT, USA). The nitrite concentration was calculated by linear regression using a curve constituted by serial solutions of sodium nitrite $(500 \mu \mathrm{M}$ to $7.8 \mu \mathrm{M})$.

\section{Splenic cells}

The splenic cell isolation was performed as described in [37]. Briefly, the cells from spleens were disaggregated mechanically using a $100 \mu \mathrm{m}$ nylon cell strainer (Thermo Fisher Scientific, Pittsburgh, USA). The cells were washed with a hypotonic buffer $\left(160 \mathrm{mM} \mathrm{NH}_{4} \mathrm{Cl}, 10 \mathrm{mM}\right.$ Tris$\mathrm{HCl}, \mathrm{pH} 7.4)$ and suspended in RPMI $\left(2 \times 10^{7}\right.$ cells $\left./ \mathrm{ml}\right)$. Cell viability was determined using a trypan blue assay (Sigma-Aldrich). The cells were assessed for phenotypic analysis, cell proliferation and apoptosis.

\section{Flow cytometry analysis}

Splenic and peritoneal cells were processed similarly as described by [35]. The cell suspensions $(100 \mu \mathrm{l} /$ tube $)$ were disposed in $12 \times 75 \mathrm{~mm}$ round-bottomed polystyrene tubes (Falcon, USA) in staining buffer (BD-Pharmingen, San Diego, USA) and blocked using a Fc receptor blocking antibody (anti-CD32, BD-Pharmingen, San Diego, USA) for $20 \mathrm{~min}$, at $4{ }^{\circ} \mathrm{C}$ in the dark. Peritoneal cells were labeled with anti-rat macrophage subset ${ }^{+} / \mathrm{PE}$ and/ or anti-rat $\mathrm{RT}_{1 \mathrm{~B}}{ }^{+} / \mathrm{PerCP}$ (catalogue numbers: 554901 and 557016, respectively. The splenic cells were incubated with the following monoclonal antibodies: anti-rat $\mathrm{CD}^{+} / \mathrm{APC}$ (catalogue number: 557030), anti-rat $\mathrm{CD} 4^{+} /$ PECy-7 (catalogue number: 561578), anti-rat $\mathrm{CD}^{+} /$ PercP (catalogue number: 558824), anti-rat $\mathrm{CD}_{45 \mathrm{RA}^{+} /}$ PE (catalogue number: 551402), anti-rat CD161a ${ }^{+} /$FITC (catalogue number: 555008). All antibodies were purchased from BD Biosciences Pharmingen, CA, USA. The data acquisition was performed in a FACS Canto flow cytometer (BD Biosciences, California, USA) equipped with the FACSDiva software.

\section{Trypanosoma cruzi protein extract}

For evaluation of the cell proliferation and apoptosis under determined stimulation, T. cruzi proteins extracts were obtained as described by Camargo et al. [38]. Trypomastigote forms ( $\mathrm{Y}$ strain) were harvested from cells cultures (LLCMK2 lineage) and filtered with a $5 \mu \mathrm{m}$ filter syringe. The parasites $\left(1 \times 10^{8} / \mathrm{ml}\right)$ were washed with phosphate-buffered saline (PBS) and suspended in RPMI. The suspensions were sonicated (two sonication cycles at $20 \mathrm{KHz}, 30$ watts in a QSonic sonicator, Cole Parmer, USA), centrifuged for $10 \mathrm{~min}, 10,000 \times g, 4{ }^{\circ} \mathrm{C}$ and the supernatant filtered with a $0.22 \mu \mathrm{m}$ filter syringe. The protein concentration of the T. cruzi extract (supernatant) was determined using a Bradford protein assay (Pierce $^{\mathrm{TM}}$ Coomassie/Bradford Protein Assay Kit, ThermoFisher Scientific, Waltham, USA). The concentration was then normalized to $3 \mathrm{mg} / \mathrm{ml}$.

\section{T cell proliferation}

The $T$ cell proliferation was evaluated by a CFSE (carboxyfluorescein succinimidyl ester) assay, as described in [39]. The splenic cells $\left(1 \times 10^{5} /\right.$ tube $)$ in RPMI were centrifuged $\left(1500 \times g, 4^{\circ} \mathrm{C}, 3 \mathrm{~min}\right)$ and suspended in $100 \mu \mathrm{l}$ PBS. The cells were incubated with $5 \mu \mathrm{M}$ carboxyfluorescein succinimidyl ester (CFSE, BD Biosciences Pharmingen, Franklin Lakes, USA) for $10 \mathrm{~min}$, at $37^{\circ} \mathrm{C}$ in the dark. The extracellular CFSE was blocked with RPMI supplemented with FBS (5\%) and incubated for $5 \mathrm{~min}$ at room temperature. After incubation, the samples were centrifuged at $3500 \times g$ for $1 \mathrm{~min}$ at $4{ }^{\circ} \mathrm{C}$ and suspended in RPMI. The CFSE-labeled cells were divided into two groups. The first group (day 0) was incubated for $15 \mathrm{~min}, 37^{\circ} \mathrm{C}, 5 \%$ $\mathrm{CO}_{2}$ and analyzed by flow cytometry. The second group was disturbed in 96-well plates and incubated for 4 days (day 4), at $37{ }^{\circ} \mathrm{C}$ and $5 \% \mathrm{CO}_{2}$ with RPMI (control), $2.5 \mu \mathrm{g} /$ $\mathrm{ml}$ Concanavalin A (ConA, Sigma-Aldrich) or $300 \mu \mathrm{g} / \mathrm{ml}$ T. cruzi protein extract. After incubation, the cells were transferred to $12 \times 75 \mathrm{~mm}$ round-bottomed polystyrene tubes and washed three times with PBS. For tubes from days 0 or 4 , the flow cytometry analysis was performed similarly. The samples were blocked with Fc receptor blocking (anti-CD32, BD-Pharmingen) for $20 \mathrm{~min}$, at $4{ }^{\circ} \mathrm{C}$ in the dark. The cells were washed with PBS and labeled with anti-rat $\mathrm{CD}^{+} / \mathrm{APC}$ (BD Biosciences Pharmingen, catalogue number: 557030). The decrease of CFSE intensity of the $\mathrm{CD}^{+}$population due to cell division was measured using CellQuest software (Becton Dickinson, San Jose, CA, USA).

\section{Apoptosis analysis (Annexin and PI)}

The apoptosis evaluation was performed as described in [40]. The splenic cells $\left(1 \times 10^{6} / \mathrm{ml}\right)$ in 96 -well plates $(100 \mu \mathrm{l} /$ well $)$ were incubated for $24 \mathrm{~h}, 37^{\circ} \mathrm{C}, 5 \% \mathrm{CO}_{2}$ with 
T. cruzi extract $(300 \mu \mathrm{g} / \mathrm{ml})$ or RPMI (control). In parallel, the same approach was performed for $15 \mathrm{~min}$. After incubation, the cells were transferred to $12 \times 75 \mathrm{~mm}$ round-bottomed polystyrene tubes $(100 \mu \mathrm{l} /$ tube), washed twice with PBS and centrifuged for $3 \mathrm{~min}, 2500 \times g, 4{ }^{\circ} \mathrm{C}$. The cells were suspended in Annexin-V FITC solution $(1 \mu \mathrm{l}$ Annexin-V FITC in $100 \mu \mathrm{l}$ Annexin Binding Buffer, BD Biosciences Pharmingen) and incubated for $15 \mathrm{~min}$, at room temperature, in the dark. Before the flow cytometry analysis, the cells received propidium iodide (PI, BD Biosciences Pharmingen). Early (Annexin ${ }^{+} \mathrm{PI}^{-}$) and late $\left(\right.$ Annexin ${ }^{+} \mathrm{PI}^{+}$) apoptosis were determined after analysis in a FACSCanto flow cytometer (BD Biosciences) equipped with the FACSDiva software.

\section{Cytokine quantification}

The levels of IFN- $\gamma$, IL-12 and IL- 6 were quantified using specific two-site enzyme-linked immunosorbent assay (ELISA) according to the manufacturer's specifications and using reference standard curves. The samples (6 animals/group) were analyzed in duplicate and the plates read in an ELISA reader at $450 \mathrm{~nm}$. All kits were purchased from RD Systems (DuoSet ELISA, Minneapolis, MN, USA).

\section{Cardiac parasite burden}

The parasite burden in hearts was analyzed by counting after hematoxylin-eosin staining, as described in [41]. Briefly, hearts were immersed in $10 \%$ buffered formaldehyde and paraffin-embedded. The tissue was cut into $6 \mu \mathrm{m}$ sections and stained with hematoxylin-eosin for evaluation of parasite burden and inflammation by optical microscopy. Parasite burden was estimated in sections separated at $70 \mu \mathrm{m}$ intervals to avoid the recount of amastigote nests. The microscopic fields were analyzed at $400 \times$ magnification and all amastigote nests counted.

\section{Statistical analysis}

Statistical analysis was performed using the program Graph Pad PRISM 5.0 (Graph Pad, USA). Data were analyzed using ANOVA followed by Tukey's post-hoc test or unpaired Student's t test (Figs. 9 and 10). All the results were expressed as mean with standard deviation. Differences were considered statistically significant at $P<0.05$.

\section{Results}

\section{Ghrelin decreased the weight of animals}

The ghrelin supplementation significantly decreased (ANOVA: $\left.F_{(3,19)}=12.96, \quad P<0.0001\right)$ the weight of infected (IG) and non-infected (CG) animals, compared to the control (post-hoc tests: C vs CG, $P=0.0004$; $C$ vs IG, $P=0.0006)$ or the infected groups (post-hoc tests: I vs CG, $P=0.086$; I vs IG, $P=0.0133$ ) (Fig. 1 ).

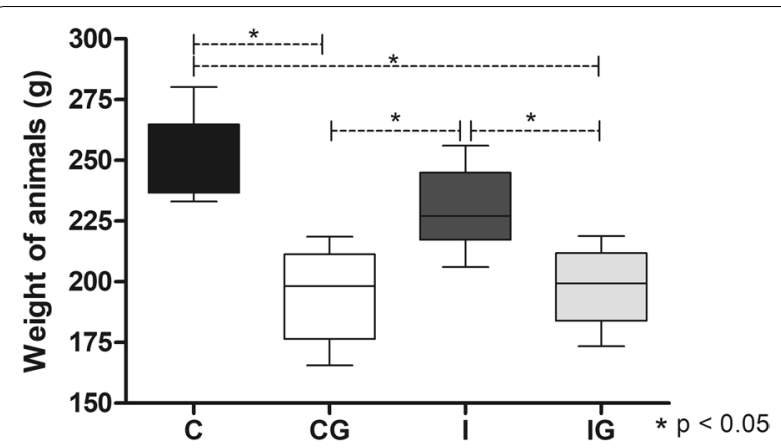

Fig. 1 Weight of animals infected with T. cruzi and/or treated with ghrelin. Male Wistar rats were infected with T. cruzi and treated for 14 days with ghrelin. On day 15 post-treatment the animals were weighed in a balance and the results represented as grams (g). Abbreviations: C, non-infected and non-treated control; CG, non-infected and treated control; I, infected and non-treated animals; $I G$, infected and treated animals. ${ }^{*} P<0.05$

\section{Macrophage analysis and nitric oxide quantification}

The macrophage subset was not altered in animals infected with T. cruzi and/or supplemented with ghrelin (Fig. 2a). However, when macrophages that express MHC class II $\left(\mathrm{RT}_{1}{ }^{+}\right)$were analyzed (ANOVA: $F_{(3,15)}=27.56$, $P<0.0001$ ), the treatment with ghrelin (IG) significantly improved $\mathrm{RT} 1 \mathrm{~B}^{+}$population in comparison to the infected group (post-hoc test: I vs IG, $P=0.0061$ ), which was also elevated in relation to the control (post-hoc tests: $C$ vs IG, $P<0.0001)$ and non-infected and treated animals (post-hoc test: CG vs IG, $P<0.0001$ ) (Fig. 2b). The T. cruziinfected animals (I) demonstrated an elevation (ANOVA: $\left.F_{(3,11)}=13.06, P=0.0006\right)$ in nitric oxide production when compared to the control (post-hoc test: C vs I, $P=0.0003$ ) and the non-infected and treated group (post-hoc test: CG vs $\mathrm{I}, P=0.0214)$. The ghrelin supplementation in infected animals (IG) also improved the nitric oxide levels in relation to the control (post-hoc test: C vs IG, $P=0.0005$ ), whereas non-significant alteration was observed compared to the infected animals (I) (Fig. 3).

\section{NK and NKT cells}

The T. cruzi infection and ghrelin supplementation elevated the NK (ANOVA: $F_{(3,16)}=16.77, P<0.0001$ ) and NKT (ANOVA: $\left.F_{(3,14)}=68.39, P<0.0001\right)$ cells compared to the non-infected and non-treated $(C)$ or the noninfected and treated (CG) counterparts (Fig. 4). The NK cells maintained a constant proportion among controls (C and CG) and the T. cruzi infected group (I), whereas the parameter significantly improved in the infected and treated animals (post-hoc tests: IG vs C, $P=0.0007$; IG vs CG, $P=0.0038$; IG vs I, $P=0.0023$ ) (Fig. 4a). In contrast, the $T$. cruzi infection (I) elevated the proportion of NKT cells compared to the control groups (post-hoc 

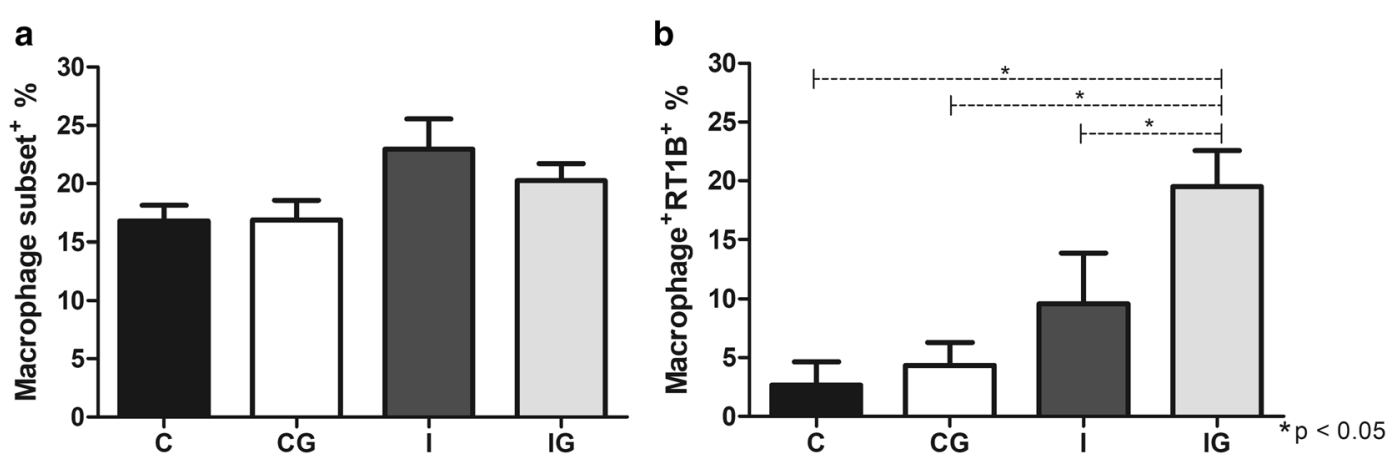

Fig. 2 Analysis of peritoneal cells. Male Wistar rats were infected with T. cruzi and treated for 14 days with ghrelin. On day 15 post-infection, the animals were euthanized and the peritoneal cells collected. The cells were labelled with anti-rat macrophage subset ${ }^{+} / \mathrm{PE}$ and/or anti-rat RT1B ${ }^{+} /$ PerCP antibodies and analyzed by flow cytometry. a Macrophage subset ${ }^{+}$populations. b Macrophage ${ }^{+}$RT1B $^{+}$populations. Abbreviations: C, non-infected and non-treated control; CG, non-infected and treated control; I, infected and non-treated animals; IG, infected and treated animals. ${ }^{*} P<0.05$

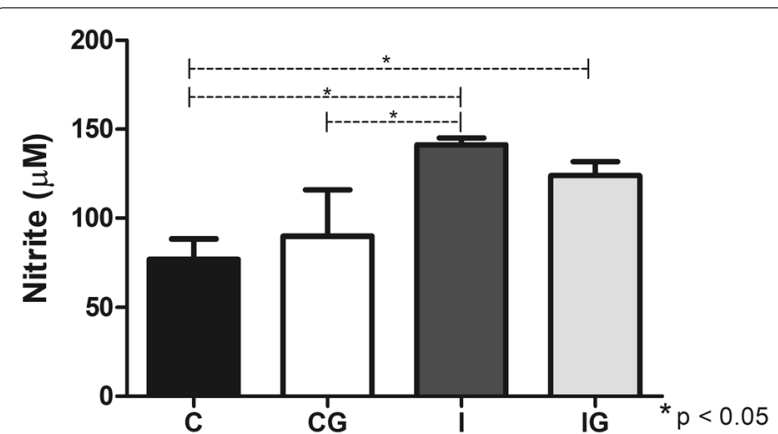

Fig. 3 Nitric oxide quantification. Male Wistar rats were infected with T. cruzi and treated for 14 days with ghrelin. On day 15 post-infection, the animals were euthanized and the peritoneal exudate collected. Peritoneal cells $\left(1 \times 10^{6}\right.$ cells $\left./ \mathrm{ml}\right)$ were incubated with LPS for $48 \mathrm{~h}$ and the nitric oxide measured by Griess method, using serial dilutions of sodium nitrite as a reference. Abbreviations: $C$, non-infected and non-treated control; CG, non-infected and treated control; I, infected and non-treated animals; $I G$, infected and treated animals. ${ }^{*} P<0.05$ tests: $\mathrm{C} v s$ I, $P<0.0001$; CG vs $\mathrm{I}, P<0.0001)$, which was maintained after ghrelin treatment (post-hoc tests: IG vs C, $P<0.0001$; IG vs CG, $P=0.0002$ ) (Fig. 4b).

\section{$\mathrm{CD}^{+}$and $\mathrm{CD}^{+}$analysis}

The $\mathrm{CD}^{+}$cells increased under $T$. cruzi infection (ANOVA: $F_{(3,15)}=38.69, \quad P<0.0001$ ), whereas $\mathrm{CD}_{4}^{+}$ cells were unresponsive, even after ghrelin treatment (Fig. 5). Treatment of infected animals with ghrelin significantly decreased the $\mathrm{CD} 8^{+}$cells (post-hoc test: I vs IG, $P=0.006$ ); however, the population remained elevated when compared to the controls (post-hoc tests: IG vs C, $P$ $=0.0049$; IG vs CG, $P=0.0105$; I vs $\mathrm{C}, P<0.0001$; I vs CG, $P<0.0001)$ (Fig. 5b).

\section{T cell proliferation}

In general, the $\mathrm{T}$ cells from infected animals proliferated under unspecific (ConA) and specific (T. cruzi extract)
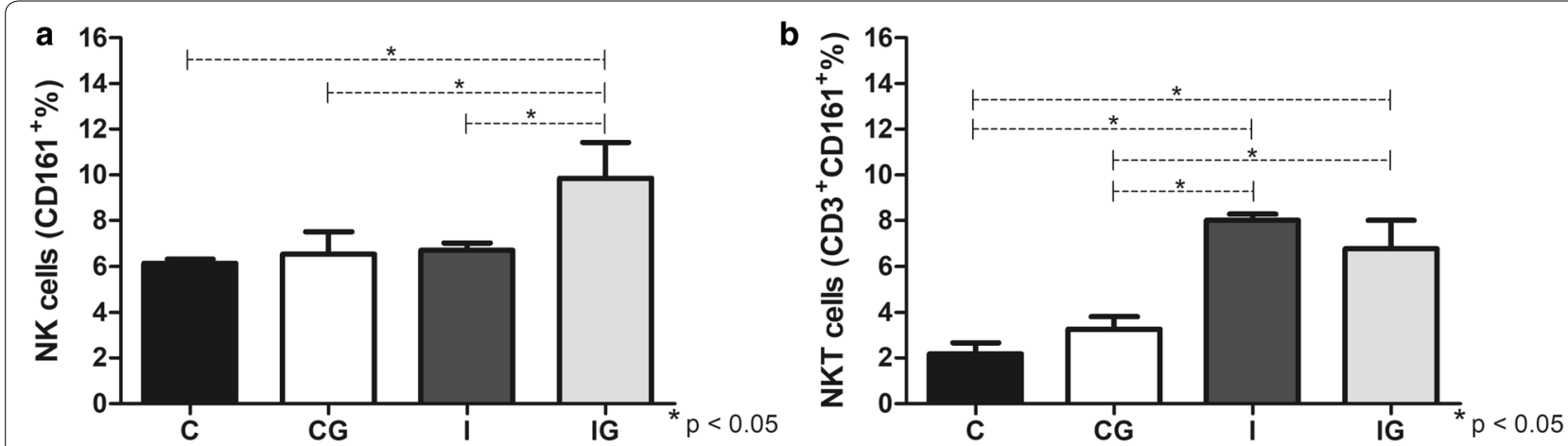

Fig. $4 \mathrm{NK}\left(\mathrm{CD}_{161^{+}}\right)$and $\mathrm{NKT}\left(\mathrm{CD}^{+}{ }^{+} \mathrm{CD} 161^{+}\right)$analysis. Male Wistar rats were infected with T. cruzi and treated for 14 days with ghrelin. On day 15 post-infection, the animals were euthanized and the spleens collected. The splenic cells were harvested and processed for NK $\left(C D 161^{+}\right)$and NKT $\left(\mathrm{CD}^{+}{ }^{+} \mathrm{CD}_{161^{+}}\right)$detection. The cells were labelled with anti-rat CD161a $/$/FITC and/or anti-rat TCD3 ${ }^{+} / \mathrm{APC}$ antibodies and analyzed by flow cytometry. a NK $\left(\mathrm{CD}_{161^{+}}\right)$populations. b NKT $\left(\mathrm{CD}^{+}{ }^{+} \mathrm{CD} 161^{+}\right)$populations. Abbreviations: $\mathrm{C}$, non-infected and non-treated control; $\mathrm{CG}$, non-infected and treated control; I, infected and non-treated animals; IG, infected and treated animals. ${ }^{*} P<0.05$ 

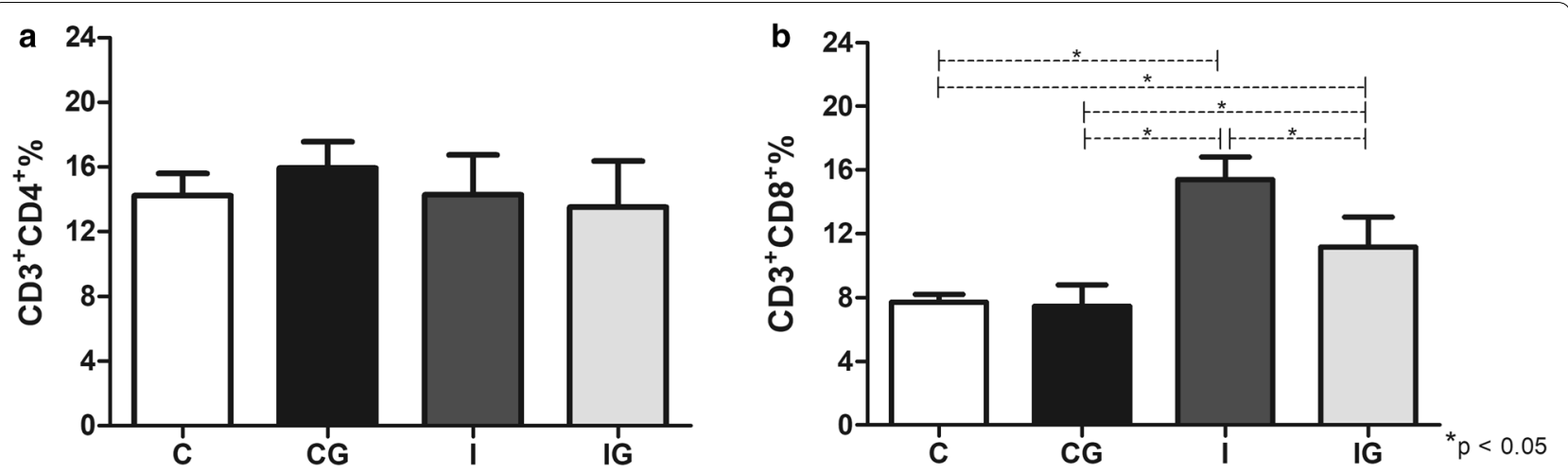

Fig. $5 \mathrm{CD}^{+}$and $\mathrm{CD}^{+}$populations. Male Wistar rats were infected with T. cruzi and treated for 14 days with ghrelin. On day 15 post-infection, the animals were euthanized and the spleens collected. The splenic cells were harvested and processed for $\mathrm{CD} 4^{+}\left(\mathrm{CD}^{+}{ }^{+} \mathrm{CD} 4^{+}\right)$and $\mathrm{CD} 8^{+}\left(\mathrm{CD}^{+} \mathrm{CD} 8^{+}\right)$ evaluation. For the $T$ cell subset detection, the suspensions were labelled first with anti-rat $\mathrm{CD}^{+} / \mathrm{APC}$, followed by a specific separation using anti-rat $\mathrm{CD} 4^{+} / \mathrm{PECy}-7\left(\mathrm{TCD} 4^{+}\right)$or anti-rat $\mathrm{CD} 8^{+} /$PercP $\left(\mathrm{TCD} 8^{+}\right)$. a $\mathrm{CD} 4^{+}\left(\mathrm{CD}^{+} \mathrm{CD}^{+}\right)$populations. $\mathbf{b} \mathrm{CD}^{+}\left(\mathrm{CD}^{+} \mathrm{CD}^{+}\right)$populations. Abbreviations: C, non-infected and non-treated control; CG, non-infected and treated control; I, infected and non-treated animals; IG, Infected and treated animals. $* P<0.05$

stimulation, mostly when incubated for 4 days (Fig. 6). The ghrelin treatment on the non-infected control (CG) indicated a pro-proliferative pattern compared to the non-supplemented counterpart $(C)$. The cell proliferation of CG animals was elevated in cultures incubated for 15 min (ANOVA: $F_{(3,18)}=26.66, P<0.0001 ; F_{(3,16)}=4.59$, $P=0.0168$; and $F_{(3,18)}=9.46, P=0.0006$ for Fig. 6a, $\mathrm{c}$ and e, respectively) in all conditions compared to the nontreated control (post-hoc tests: RPMI, $P<0.0001$; ConA, $P=0.0002$; and T. cruzi extract, $P=0.0004$ ). When incubated for 4 days (ANOVA: $F_{(3,16)}=11.94, P=0.0002$; $F_{(3,15)}=20.95, P<0.0001$; and $F_{(3,15)}=23.39, P<0.0001$ for Fig. 6b, d and f, respectively), the proliferation from CG groups was elevated only in the RPMI groups (posthoc test: $P=0.0034$ ), whereas in ConA and T. cruzi extract the proliferation was similar to the control (C) group (Fig. 6a, b, c and e). The infection with T. cruzi (I) improved the $\mathrm{T}$ cell proliferation in all conditions compared to the non-infected $(C)$ control (post-hoc tests: the $P$-values for I vs $C$ groups were $P<0.0001, P=0.0002$, $P<0.0001, P<0.0001, P=0.0092$ and $P<0.0001$ for $\mathrm{a}, \mathrm{b}$, $\mathrm{c}, \mathrm{d}$, e and f, respectively) (Fig. 6). The $\mathrm{T}$ cells from the infected group (I) were also responsive to specific ( $T$. cruzi extract) and unspecific (ConA) stimuli (Fig. 6c-f). However, compared to the ghrelin-treated and noninfected groups (CG), the infection with T. cruzi (I) stimulated the $\mathrm{T}$ cell proliferation only the samples incubated with CoA (post-hoc test: $P<0.0001$ ) and T. cruzi (post-hoc test: $P=0.0002$ ) for 4 days (Fig. $6 \mathrm{~d}$ and $\mathrm{f}$ ). The treatment with ghrelin in $T$. cruzi infected animals (IG) indicated an antiproliferative pattern (post-hoc tests: the $P$-values for I vs IG groups were $P=0.0197, P=0.0172, P=0.0004$, $P=0.0013, P=0.0012$ for Fig. $6 \mathrm{a}, \mathrm{b}, \mathrm{c}, \mathrm{d}$ and $\mathrm{f}$, respectively), except for the group incubated for 15 min under
T. cruzi extract (Fig. 6e). However, the lower proliferation observed in IG animals in relation to infected ones (I) was superior when compared to the control (C) group (post-hoc tests: the $P$-values for IG vs $\mathrm{C}$ groups were $P=0.0008, P=0.0425$ and $P=0.0147$ for Fig. $6 \mathrm{a}, \mathrm{d}$ and $f$, respectively), except for cultures incubated with RPMI for 4 days and ConA and T. cruzi for 15 min (Fig. 6).

\section{Early and late apoptosis}

The effects of T. cruzi infection in the early and late apoptosis were observed only when cells were incubated for $24 \mathrm{~h}$ (ANOVA: $F_{(3,14)}=9.07, P=0.0014 ; F_{(3,12)}=12.01$, $P=0.0006, F_{(3,15)}=18.92, P<0.0001$; and $F_{(3,14)}=13.26$, $P=0.0002$ for Fig. $7 \mathrm{c}, \mathrm{d}, \mathrm{e}$ and $\mathrm{f}$, respectively). In these groups, the infection improved both Annexin $\mathrm{V}^{+} \mathrm{PI}^{-}$ (early) and Annexin $\mathrm{V}^{+} \mathrm{PI}^{+}$(late) populations compared to the non-infected/non-treated controls (post-hoc tests: the $P$-values for I $v s \mathrm{C}$ groups were $P=0.046, P=0.0018$, $P=0.0240$ and $P=0.0033$ for Fig. $7 \mathrm{c}-\mathrm{f}$ ). The high early and late apoptosis processes during T. cruzi infection were reverted after ghrelin supplementation in all conditions (post-hoc tests: the $P$-values for I $v$ IG groups were $P<0.0001, P<0.0001, P=0.0012, P=0.0007, P=0.0099$ and $P=0.0139$ for Fig. $7 \mathrm{a}-\mathrm{f}$, respectively). A similar pattern was observed when infected and treated animals were compared to the non-infected and non-treated counterparts (post-hoc tests: the $P$-values for IG vs CG groups were $P<0.0001, P=0.0011, P=0.042, P=0.034$, $P<0.0001$ and $P=0.0033$ for Fig. $7 \mathrm{a}-\mathrm{f}$, respectively). The apoptosis from animals treated with ghrelin (IG) was similar to the observed in the control $(C)$. However, for cells incubated for 15 min (ANOVA: $F_{(3,15)}=22.01$, $P<0.0001$; and $F_{(3,19)}=12.06, P=0.0001$ for Fig. 7 a and $b$, respectively), the early and late apoptosis from infected 

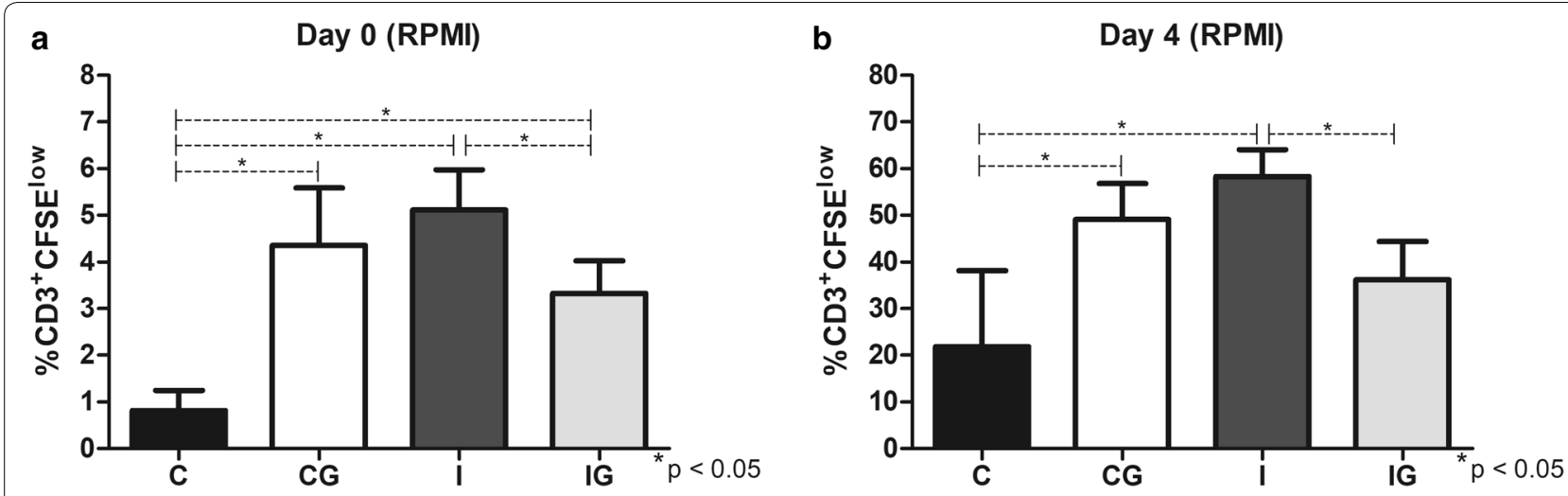

C

Day 0 (ConA)

d

Day 4 (ConA)
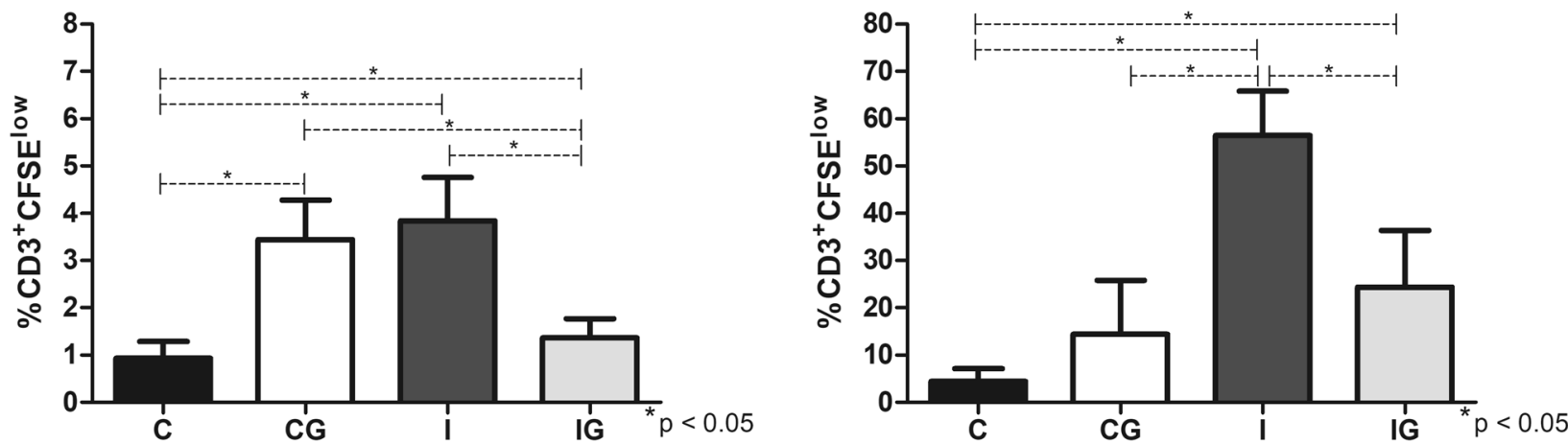

e

Day 0 (T. cruzi)

f

Day 4 (T. cruzi)
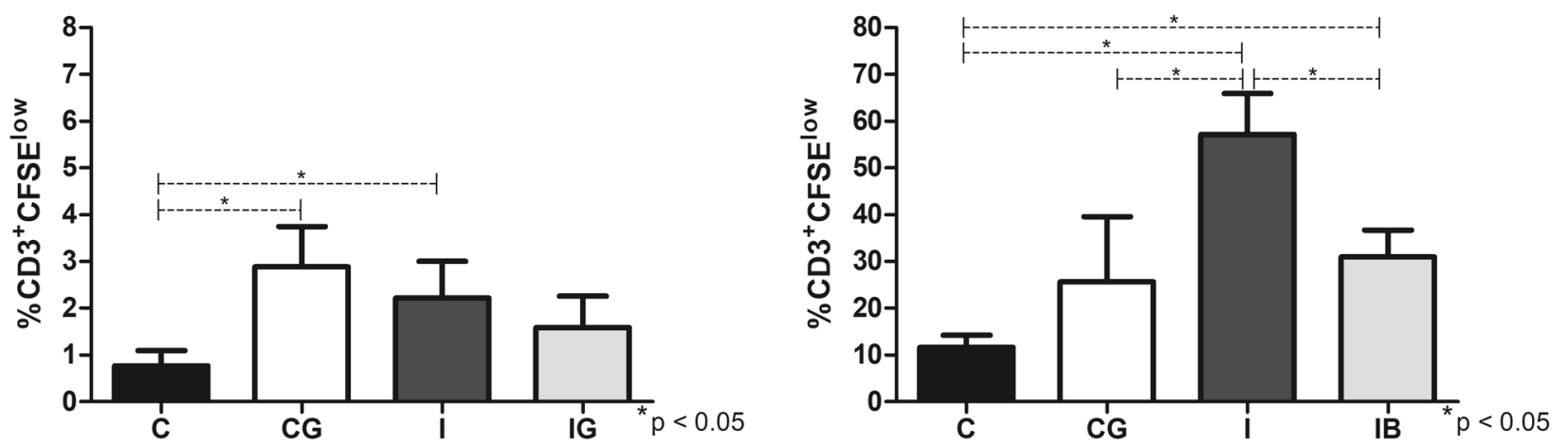

Fig. 6 Evaluation of T cell proliferation by CFSE. Male Wistar rats were infected with T. cruzi and treated for 14 days with ghrelin. On day 15 post-infection, the animals were euthanized and the spleens collected. The splenic cells were processed, labelled with CFSE and incubated with ConA, T. cruzi extract or RPMI (control) for 4 days, $37^{\circ} \mathrm{C}, 5 \% \mathrm{CO}_{2}$. In parallel, the same approach was performed with incubation for 15 min (day 0 ). The $T$ cell population was distinguished using anti-rat $\mathrm{CD}^{+} / \mathrm{APC}$ antibody and the proliferation analyzed by flow cytometry. a Proliferation for 15 min (day 0) with RPMI. b Proliferation for 4 days (day 4) with RPMI. c Proliferation for 15 min (day 0) with ConA. d Proliferation for 4 days (day 4) with ConA. e Proliferation for 15 min (day 0) with T. cruzi extract. f Proliferation for 4 days (day 4) with T. cruzi extract. Abbreviations: C, non-infected and non-treated control; CG, non-infected and treated control; I, infected and non-treated animals; IG, infected and treated animals. ${ }^{*} P<0.05$

and treated groups (IG) was lower than the control (C) (post-hoc tests: the $P$-values of IG vs $\mathrm{C}$ groups were $P=0.0024$ and $P=0.0097$ for Fig. 7 a and b, respectively). In non-infected animals, the ghrelin supplementation
(CG) improved the late apoptosis in groups incubated for $24 \mathrm{~h}$ compared to the control (C) (post-hoc tests: the $P$-values of CG vs $C$ groups were $P<0.0001$ and $P=0.0007$ for Fig. 7e and f, respectively). 

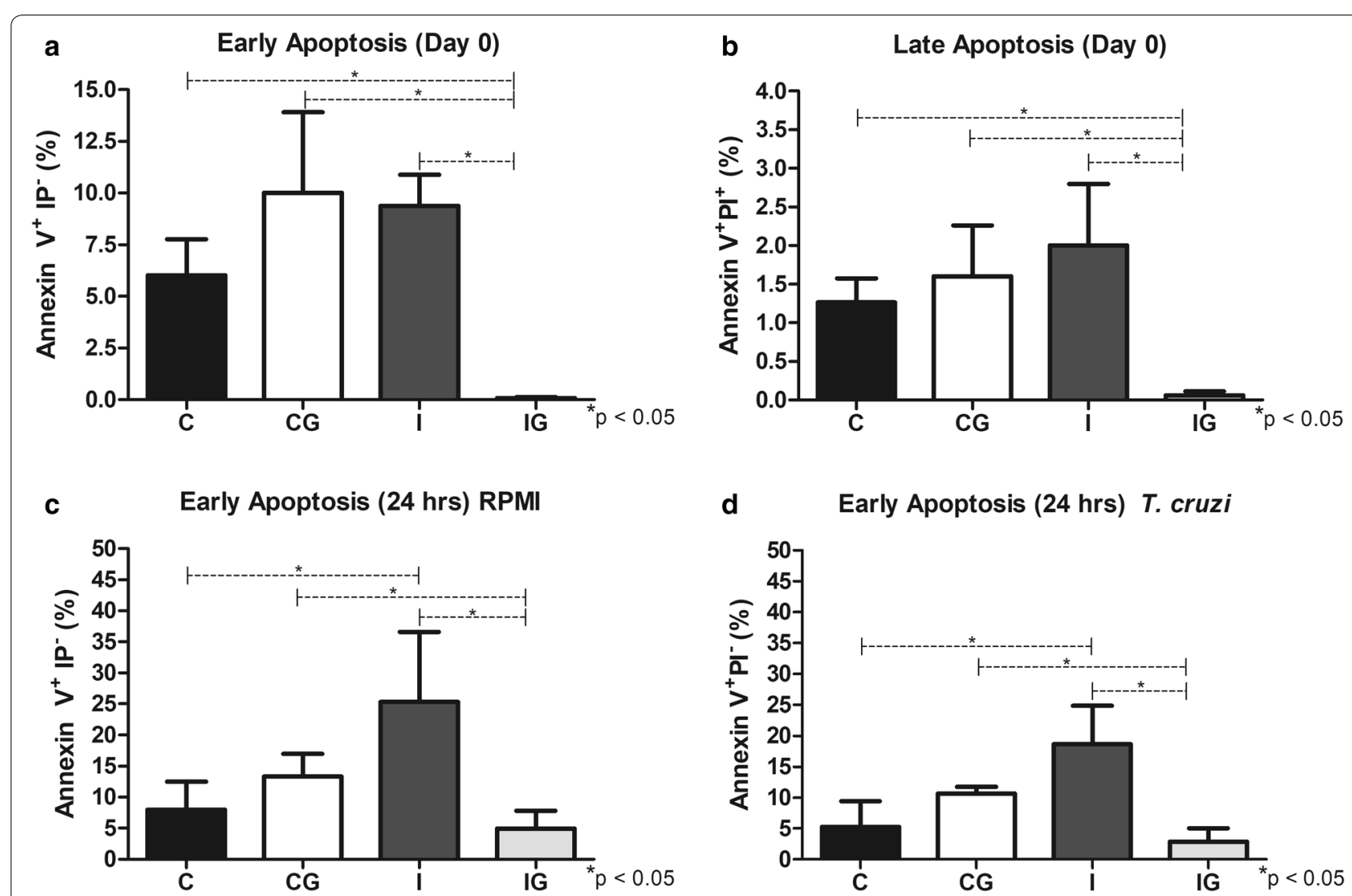

e Late Apoptosis (24 hrs) RPMI
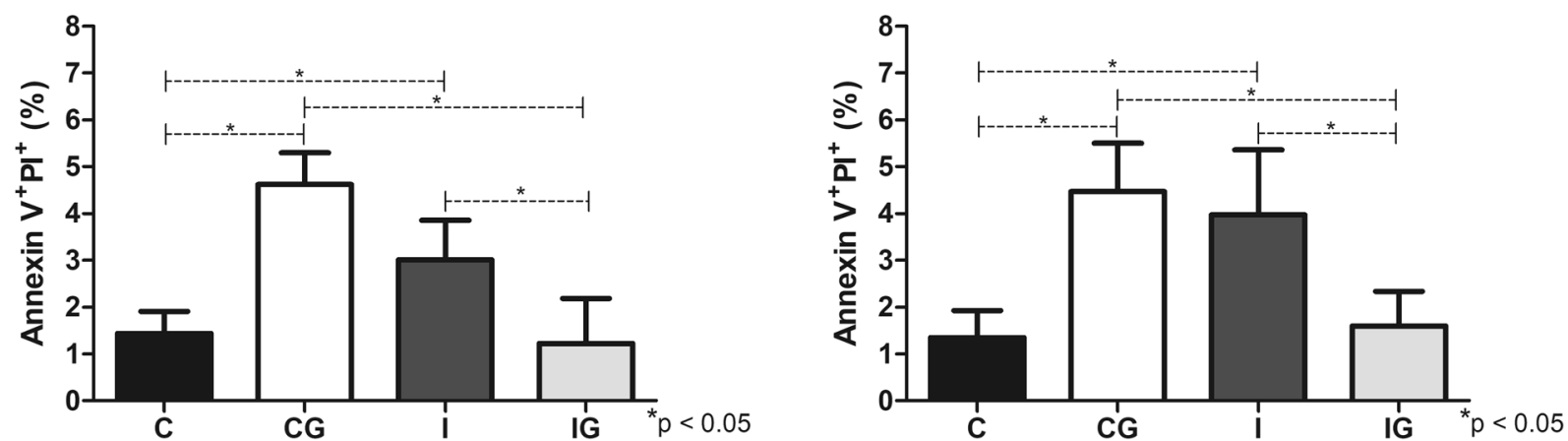

Fig. 7 Early and late apoptosis of splenic cells. Male Wistar rats were infected with T. cruzi and treated for 14 days with ghrelin. On day 15 post-infection, the animals were euthanized and the spleens collected. The splenic cells were processed, labelled with CFSE and incubated with T. cruzi extract or RPMI (control) for $24 \mathrm{~h}, 37^{\circ} \mathrm{C}, 5 \% \mathrm{CO}_{2}$. In parallel, the same approach was performed with incubation for $15 \mathrm{~min}$ (day 0). The cells were incubated with Annexin-V FITC for 15 min, at room temperature in the dark. Before the analysis by flow cytometry, propidium iodide was added. a Early apoptosis (AnnexinV $\mathrm{PI}^{+}$) of cells incubated for $15 \mathrm{~min}$ with RPMI. $\mathbf{b}$ Late apoptosis (AnnexinV $\mathrm{PI}^{+}$) of cells incubated for 15 min with RPMI. c Early apoptosis (AnnexinV $\mathrm{V}^{+} \mathrm{PI}^{-}$) of cells incubated for $24 \mathrm{~h}$ with RPMI. d Early apoptosis (AnnexinV $\mathrm{V}^{+} \mathrm{Pl}^{-}$) of cells incubated for $24 \mathrm{~h}$ with $\mathrm{T}$. cruzi extract. e Late apoptosis (AnnexinV ${ }^{+} \mathrm{Pl}^{+}$) of cells incubated for $24 \mathrm{~h}$ with RPMI. $\mathbf{f}$ Late apoptosis (AnnexinV ${ }^{+} \mathrm{Pl}^{+}$) of cells incubated for $24 \mathrm{~h}$ with T. cruzi extract. Abbreviations: C, non-infected and non-treated control; CG, non-infected and treated control; I, infected and non-treated animals; IG, infected and treated animals. ${ }^{*} P<0.05$

\section{Cytokine quantification}

The infection with $T$. cruzi elevated the levels of INF- $\gamma$ (ANOVA: $F_{(3,31)}=7.096, P=0.0009$ ) and IL-12 (ANOVA: $\left.F_{(3,16)}=10.20, P=0.0005\right)$ compared to the non-infected and non-treated control (post-hoc tests: the $P$-values of I vs $C$ groups were $P=0.0009$ and $P=0.003$ for Fig. $8 \mathrm{a}$ and $\mathrm{b}$, respectively) or the non-infected and treated control (CG) (post-hoc test : the $P$-values of I vs CG groups were 
$P=0.0059$ and $P=0.0414$ for Fig. 8 a and b, respectively). However, the T. cruzi infection did not alter the IL-6 levels (ANOVA: $\left.F_{(3,16)}=10.61, P=0.0004\right)$ compared to the non-treated controls (Fig. 8c). The treatment with ghrelin in infected animals decreased all cytokine levels (posthoc tests: the $P$-values of IG $v s$ I groups were $P=0.032$, $P=0.0005$ and $P=0.0007$ for Fig. $8 \mathrm{a}, \mathrm{b}$ and $\mathrm{c}$, respectively) and no alteration was observed when non-infected controls (CG) were treated (Fig. 8).

\section{Parasitemia and cardiac parasite burden}

The treatment with ghrelin did not alter the blood parasitemia on day 8 post-infection (Fig. 9). In hearts (t-test: $\left.t_{(7)}=2.458, P=0.0063\right)$ the treatment with ghrelin elevated the number of amastigotes nests compared to the infected and non-treated group (I vs IG, $P=0.0419$ ) (Fig. 10). However, when amastigotes nests were analyzed by microscopy, the treatment with ghrelin (IG) demonstrated a lower presence of inflammatory infiltration (Fig. 11b, d) in relation to the T. cruzi-infected group (I) (Fig. 11a, c).

\section{Discussion}

A complex cellular and humoral immune response is mobilized against $T$. cruzi infection, performing an import role in the parasite-host relationship [42, 43]. During the acute phase of Chagas disease, the trypomastigotes forms of T. cruzi are abundant in peripheral blood [44] and the transition to the chronic stage is characterized by parasite migration to tissues (e.g. heart, colon and oesophagus) concomitantly with a specific immune response. The deleterious symptoms of the chronic phase are the result of a discomposed immune response against the intracellular amastigotes, which usually result in inflammation and tissue lesions. Once ghrelin has an anti-inflammatory pattern in diverse models [45], a set of assays are necessary to determinate the ghrelin effects during Chagas disease.

The pro-metabolic effect of ghrelin is observed in the rat model. The peptide administration decreased the animal weight, a consequence of the use of ghrelin in the control of obesity and metabolic-related disorders [46]. The weight loss verified in ghrelin-treated animals was not influenced by $T$. cruzi infection, which indicates the use of ghrelin as a metabolic regulator in endemic areas [47]. However, restrictions should be considered for the correct use of ghrelin in models also affected by malnutrition, which may lead to aggravation of Chagas disease symptoms. Indeed, authors have correlated the aggravation of T. cruzi infection with deprivation of nutrients [48]. For obese models infected with T. cruzi, ghrelin probably has a dual effect. Besides the weight loss, ghrelin decreases the TNF, IL-17 and IL-12p40 mRNA expression in the hearts of obese rats [10].
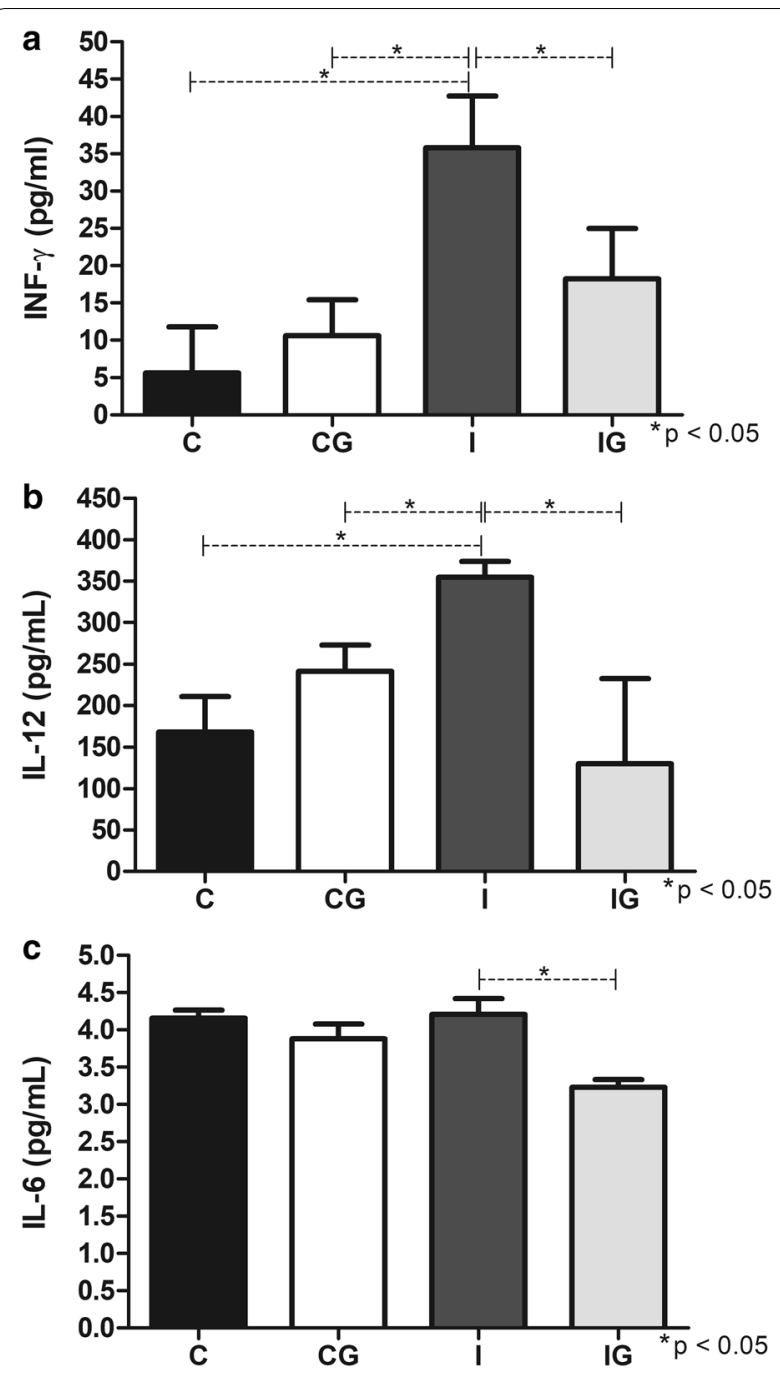

Fig. 8 Cytokine quantification. Male Wistar rats were infected with $T$. cruzi and treated for 14 days with ghrelin. On day 15 post-infection, the animals were euthanized, and the sera collected. Cytokines INF- $\gamma$ (a), IL-12 (b) and IL-6 (c) were quantified by ELISA. Abbreviations: C, non-infected and non-treated control; CG, non-infected and treated control; I, infected and non-treated animals; IG, infected and treated animals. ${ }^{*} P<0.05$

The initial phase of T. cruzi infection triggers several mechanisms of the innate response, such as nitric oxide production and activation of antigen-presentation (APCs) and NK cells [49]. The nitric oxide (NO) produced by macrophages has a pivotal anti- $T$. cruzi effect also observed in several infections caused by viruses, bacteria, fungi and protozoans [50]. The T. cruzi infection elevated the NO production, which is maintained after ghrelin administration. A constant and regulated NO production is essential to control the infection as well as avoiding tissue damage due to NO overproduction [51]. The macrophage is closely related to NO production and 


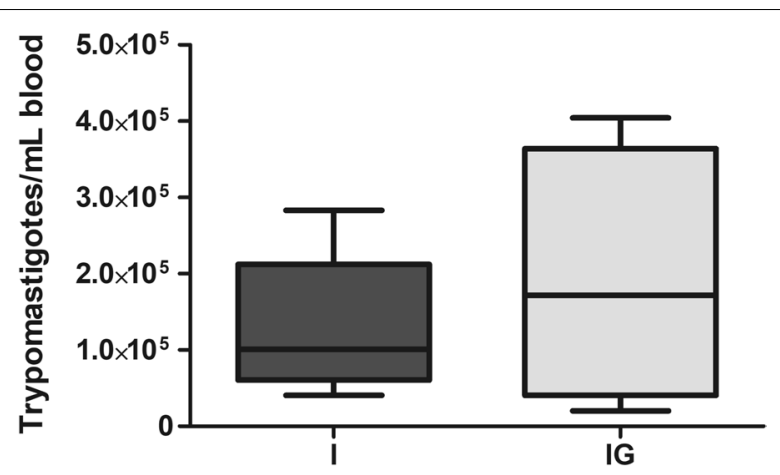

Fig. 9 T. cruzi blood parasitemia. Male Wistar rats were infected with T. cruzi and treated for 14 days with ghrelin. On day 8 post-infection, blood was collected and the trypomastigotes forms counted according to Brener's method

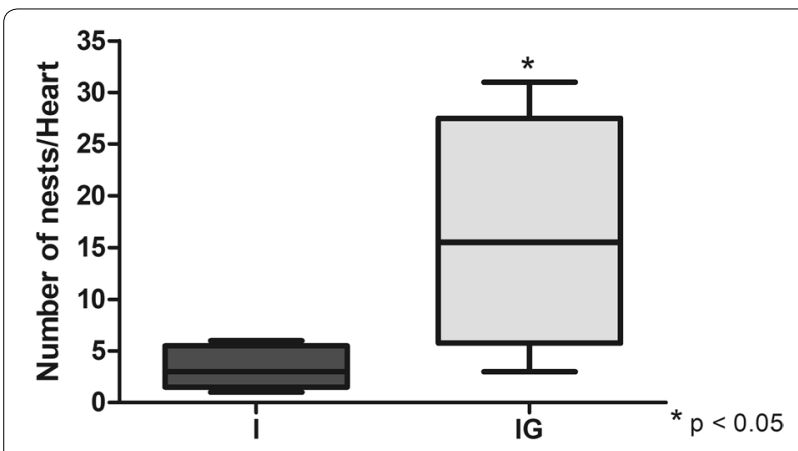

Fig. 10 Cardiac parasite burden. Male Wistar rats were infected with T. cruzi and treated for 14 days with ghrelin. On day 15 post-infection, the animals were euthanized, and the hearts collected. The cardiac tissue was prepared and hematoxylin-eosin stained for detection and counting of amastigotes nests. ${ }^{*} P<0.05$

antigen presentation during infections [52]. Therefore, a specific antigen presentation is fundamental for an effective parasite control. Ghrelin promoted the expansion of $\mathrm{MHC}$ II presenting macrophages $\left(\mathrm{RT}^{\mathrm{B}} \mathrm{B}^{+}\right)$, which are important for an adequate adaptive response against $T$. cruzi [53]. The host resistance against the acute phase of Chagas disease is also dependent on NK and NKT cells, which produce pro-inflammatory cytokines and stimulates the phagocytic activity [54, 55]. Ghrelin acts by improving the NK and NKT cells in infected animals, maintaining an anti-T. cruzi pattern. Indeed, in vitro incubation of peripheral blood from pregnant women with ghrelin elevates the NK cells proportion [56]. However, more studies are required for the complete elucidation of the ghrelin mechanisms on NK/NKT cells during Chagas disease.

Despite the positive effects of ghrelin supplementation in innate response, the administration of the peptide decreased the $\mathrm{T}$ cell populations, mostly $\mathrm{CD} 8^{+}$. The
$\mathrm{CD}^{+}$mediated response controls infections caused intracellular protozoans such as Plasmodium, Toxoplasma, Leishmania and Trypanosoma [57]. Thus, this cell population has an important role in amastigote elimination in infected tissues. However, the typical cardiac lesions observed in the chronic phase of Chagas disease have been related to inflammatory infiltrates, which are mainly composed by $\mathrm{CD}^{+}$cells [58]. During the early stages of $T$. cruzi infection, parasite antigens are presented by antigen-presenting cells (APCs) using the major histocompatibility complex (MHC I or MHC II). In lymphoid organs, MHCs interact with the $\mathrm{T}$ cell receptor (TCR) and costimulatory molecules (CD80, CD86, CD40 and CD83), resulting in activation and proliferation of naïve $\mathrm{T}$ cells [59]. T cells $\left(\mathrm{CD}^{+}\right.$and $\left.\mathrm{CD}^{+}\right)$perform an important role in the parasite control, producing cytokines (e.g. IFN- $\gamma$, IL-6 and IL-12) and factors for an effective cellular and humoral response [25]. Indeed, the levels of IFN- $\gamma$, IL- 6 and IL-12 were lower after the treatment of infected animals with ghrelin. The T. cruzi infection stimulated the proliferation of $\mathrm{CD}^{+}$cells, which was reverted after ghrelin treatment. Moreover, the low proliferation of $\mathrm{T}$ cells was followed by the elevation of parasite colonization in the heart. However, ghrelin improved the cell proliferation in non-infected cells, indicating different mechanisms in infected and healthy models. To elucidate the ghrelin mechanisms in $\mathrm{T}$ cell activation, more assays related to Th1 and Th2 response and regulation are necessary, once some of the deleterious effects of the disease are related to an exacerbated $\mathrm{CD}^{+}$mediated response [60]. The $\mathrm{T}$ cell activation and expansion during Chagas disease is also followed by the improvement of apoptosis [61]. As a survival mechanism, T. cruzi produces several factors which induce the cell apoptosis and, consequently, parasite propagation. For example, the trans-sialidase enzymes, which are related to the caption of exogenous sialic acid residues from the host to the T. cruzi surface, induce an intense process of apoptosis [62, 63]. Ghrelin acts as a potent antiapoptotic molecule during the acute phase of Chagas disease, decreasing the Annexin ${ }^{+}$and/or $\mathrm{PI}^{+}$cells in all tested conditions. Indeed, ghrelin inhibits apoptosis processes in diverse cellular models [64-66], indicating its cell protective pattern. Therefore, there is a potential for the ghrelin use during the chronic phase of Chagas disease, which may decrease the damage of infected organs induced by apoptosis $[67,68]$.

Despite the pivotal role of NK cells and macrophages in the secretion of INF- $\gamma$ and IL-12 [69], our results indicate a reduction of these cytokines in animals treated with ghrelin. NK/NKT cells usually produce INF- $\gamma$ in the early stages of infections, before the establishment of an adaptive response [70]. IL-12 is 


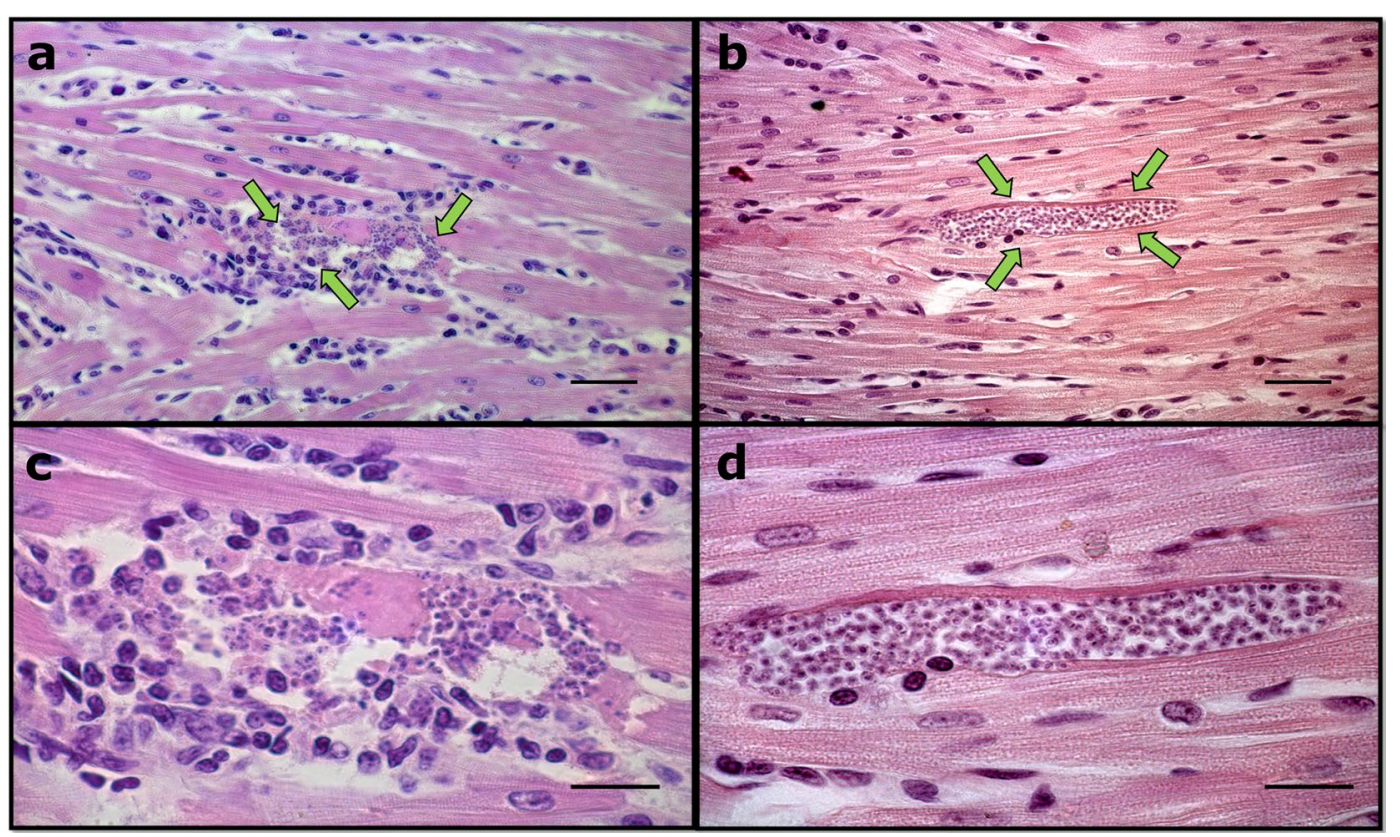

Fig. 11 Colonization of cardiac tissue with T. cruzi amastigotes. Male Wistar rats were infected with T. cruzi and treated for 14 days with ghrelin. On day 15 post-infection, the animals were euthanized, and the hearts collected. The cardiac tissue was fixed with 10\% buffered formaldehyde, paraffin-embedded and prepared for hematoxylin-eosin staining. Arrows indicate the amastigote nests. a Cardiac tissue from infected and non-treated animals $(400 \times)$. b Cardiac tissue from infected and ghrelin-treated animals $(400 \times)$. c Cardiac tissue from infected and non-treated animals $(1000 \times)$. d Cardiac tissue from infected and ghrelin-treated animals (1000x). Scale-bars: a, b 100 um; c, d, $50 \mu \mathrm{m}$

produced by antigen-presenting cells (APCs), including macrophages [71]. This cytokine stimulates $\mathrm{T}$ cell differentiation and proliferation, which also secretes INF- $\gamma[72,73]$. Additionally, the pro-inflammatory IL-6 cytokine was also decreased in infected and ghrelin treated group. IL-6 stimulates specific differentiation of naïve T CD4 cells, a crucial step for the development of an acquired immune response [74]. The cytokine also stimulates the $\mathrm{T}$ cell proliferation under inflammatory conditions [75], leading to spontaneous rheumatoid arthritis (RA)-like disease in mice [76].

Once ghrelin decreased $\mathrm{CD}^{+}$populations and the $\mathrm{CD}^{+}$cell proliferation in infected animals, the low levels of INF- $\gamma$, IL-12 and IL- 6 are probably related to the $\mathrm{T}$ cell suppression. Thus, Ghrelin promoted the innate response against $T$. cruzi and failed at promoting some points of $\mathrm{T}$ cell response (low $\mathrm{CD} 8^{+}$and $\mathrm{T}$ cell proliferation), which probably are related to the improvement of cardiac parasite burden. However, the anti-inflammatory pattern (INF- $\gamma$, IL-12 and IL-6) observed after ghrelin treatment is related to the lower presence of inflammatory infiltrates compared to the infected control. Indeed, in the chronic phase of Chagas disease, when parasite burden is usually controlled by the immune system [77], some patients demonstrate an intense inflammatory response in the cardiac tissue, mainly caused by $\mathrm{CD} 8^{+}$cells [78]. Moreover, INF- $\gamma$ and IL-6 are overproduced in lymphocytes of patients with chronic chagasic cardiopathy (CCC) compared to asymptomatic individuals $[79,80]$, thus reinforcing the anti-inflammatory propriety of ghrelin.

\section{Conclusions}

The use of ghrelin during the acute phase of Chagas disease demonstrated a dual pattern. The peptide promoted an effective innate response; however, several aspects of cell response are downregulated. Once ghrelin decreases the pro-inflammatory cytokines in serum and cell infiltrates in infected hearts, the peptide has the potential to control the main injuries caused by Chagas disease. A positive effect of ghrelin as cardio-protector, as observed in other models [30, 81, 82], will be important for therapies directed toward the alleviation of Chagas disease symptoms, improving the life quality of patients.

\footnotetext{
Abbreviations

CD: cluster of differentiation; NK: natural killer cell; NKT: natural killer T cell; NO: nitric oxide; IFN-y: interferon gamma; IL: interleukin; RPMI: Roswell Park Memorial Institute media; FBS: fetal bovine serum; ACK: ammonium-chloridepotassium; LPS: lipopolysaccharides; APC: antigen-presenting cell; CFSE: carboxyfluorescein succinimidyl ester; ConA: concanavalin A.
} 


\section{Acknowledgments}

We would like to thank Fabiana Rosetto Morais for assistance with flow cytometry.

\section{Authors' contributions}

AACA and JCPJ designed and supervised the study. FPS, CMBC, LMP, DSL and DLP carried out the laboratory experiments and sample analysis. FPS, CMBC and LMP analyzed the data and drafted the manuscript. AACA, JCPJ and JPMI reviewed the manuscript. All authors read and approved the final manuscript.

\section{Funding}

This study was supported by Fundação de Amparo à Pesquisa do Estado de São Paulo (FAPESP, process number: 2014/18682-3). This study was also financed in part by the Coordenação de Aperfeiçoamento de Pessoal de Nível Superior - Brasil (CAPES) - Finance Code 001.

\section{Availability of data and materials}

All data generated or analyzed during this study are included in this published article.

\section{Ethics approval and consent to participate}

The animal manipulation protocol was approved by the local Ethics Committee (protocol number 14.1.712.53.7.)

\section{Consent for publication}

Not applicable.

\section{Competing interests}

The authors declare that they have no competing interests.

\section{Author details}

${ }^{1}$ Department of Clinical Analyses, Toxicology and Food Science, School of Pharmaceutical Sciences of Ribeirão Preto, University of São Paulo, Ribeirão Preto 14040-903, Brazil. ${ }^{2}$ Department of Morphology, Physiology and Basic Pathology, School of Dentistry of Ribeirão Preto USP, University of São Paulo, Ribeirão Preto 14040-904, Brazil.

Received: 6 July 2019 Accepted: 4 November 2019

Published online: 09 November 2019

\section{References}

1. WHO. Chagas disease (American-trypanosomiasis). Geneva: World Health Organization. 2018. http://www.who.int/mediacentre/factsheets/fs340/ en/. Acessed 20 Feb 2018.

2. Coura JR, Vinas PA. Chagas disease: a new worldwide challenge. Nature. 2010:465:S6-7.

3. Rodriguez-Morales O, Monteon-Padilla V, Carrillo-Sanchez SC, Rios-Castro M, Martinez-Cruz M, Carabarin-Lima A, et al. Experimental vaccines against Chagas disease: a journey through history. J Immunol Res. 2015;2015:489758.

4. Quijano-Hernandez I, Dumonteil E. Advances and challenges towards a vaccine against Chagas disease. Hum Vaccin. 2011;7:1184-91.

5. Zingales B, Miles MA, Moraes CB, Luquetti A, Guhl F, Schijman AG, et al. Drug discovery for Chagas disease should consider Trypanosoma cruzi strain diversity. Mem Inst Oswaldo Cruz. 2014;109:828-33.

6. Field MC, Horn D, Fairlamb AH, Ferguson MA, Gray DW, Read KD, et al. Anti-trypanosomatid drug discovery: an ongoing challenge and a continuing need. Nat Rev Microbiol. 2017; 15:217-31.

7. Sales Junior PA, Molina I, Fonseca Murta SM, Sanchez-Montalva A Salvador F, Correa-Oliveira R, et al. Experimental and clinical treatment of Chagas disease: a review. Am J Trop Med Hyg. 2017;97:1289-303.

8. Kojima M, Hosoda H, Date Y, Nakazato M, Matsuo H, Kangawa K. Ghrelin is a growth-hormone-releasing acylated peptide from stomach. Nature. 1999:402:656-60.

9. Burger KS, Berner LA. A functional neuroimaging review of obesity, appetitive hormones and ingestive behavior. Physiol Behav. 2014;136:121-7.

10. Stevanovic D, Starcevic V, Vilimanovich U, Nesic D, Vucicevic L, Misirkic $M$, et al. Immunomodulatory actions of central ghrelin in diet-induced energy imbalance. Brain Behav Immun. 2012;26:150-8.
11. Kola B. Role of AMP-activated protein kinase in the control of appetite. J Neuroendocrinol. 2008;20:942-51.

12. Prodam F, Filigheddu N. Ghrelin gene products in acute and chronic inflammation. Arch Immunol Ther Exp (Warsz). 2014;62:369-84

13. Dixit VD, Schaffer EM, Pyle RS, Collins GD, Sakthivel SK, Palaniappan R, et al. Ghrelin inhibits leptin- and activation-induced proinflammatory cytokine expression by human monocytes and T cells. J Clin Invest. 2004;114:57-66.

14. Theil MM, Miyake S, Mizuno M, Tomi C, Croxford JL, Hosoda H, et al. Suppression of experimental autoimmune encephalomyelitis by ghrelin. J Immunol. 2009;183:2859-66.

15. Granado M, Priego T, Martin Al, Villanua MA, Lopez-Calderon A. Antiinflammatory effect of the ghrelin agonist growth hormone-releasing peptide-2 (GHRP-2) in arthritic rats. Am J Physiol Endocrinol Metab. 2005;288:E486-92.

16. Wu R, Dong W, Cui X, Zhou M, Simms HH, Ravikumar TS, et al. Ghrelin down-regulates proinflammatory cytokines in sepsis through activation of the vagus nerve. Ann Surg. 2007;245:480-6.

17. Granado M, Martin Al, Lopez-Menduina M, Lopez-Calderon A, Villanua MA. GH-releasing peptide-2 administration prevents liver inflammatory response in endotoxemia. Am J Physiol Endocrinol Metab. 2008;294:E131-41.

18. Konturek PC, Brzozowski T, Engel M, Burnat G, Gaca P, Kwiecien S, et al. Ghrelin ameliorates colonic inflammation. Role of nitric oxide and sensory nerves. J Physiol Pharmacol. 2009;60:41-7.

19. Dembinski A, Warzecha Z, Ceranowicz P, Tomaszewska R, Stachura J, Konturek SJ, et al. Ghrelin attenuates the development of acute pancreatitis in rat. J Physiol Pharmacol. 2003;54:561-73.

20. Osawa H. Ghrelin and Helicobacter pylori infection. World J Gastroenterol. 2008;14:6327-33.

21. Sehirli O, Sener E, Sener G, Cetinel S, Erzik C, Yegen BC. Ghrelin improves burn-induced multiple organ injury by depressing neutrophil infiltration and the release of pro-inflammatory cytokines. Peptides. 2008;29:1231-40

22. Huang CX, Yuan MJ, Huang H, Wu G, Liu Y, Yu SB, et al. Ghrelin inhibits post-infarct myocardial remodeling and improves cardiac function through anti-inflammation effect. Peptides. 2009;30:2286-91.

23. Wu R, Dong W, Ji Y, Zhou M, Marini CP, Ravikumar TS, et al. Orexigenic hormone ghrelin attenuates local and remote organ injury after intestinal ischemia-reperfusion. PLoS One. 2008;3:e2026.

24. Nokhbehsaim M, Nogueira AVB, Memmert S, Damanaki A, Eick S, Cirelli $J A$, et al. Regulation of ghrelin receptor by microbial and inflammatory signals in human osteoblasts. Braz Oral Res. 2019;33:e025.

25. Boscardin SB, Torrecilhas AC, Manarin R, Revelli S, Rey EG, Tonelli RR, et al. Chagas disease: an update on immune mechanisms and therapeutic strategies. J Cell Mol Med. 2010;14:1373-84.

26. Amato Neto V. Origin of the "Y strain" of Trypanosoma cruzi. Rev Inst Med Trop Sao Paulo. 2010:52:171.

27. Silva LHP, Nussenzweig V. Sobre uma cepa de Trypanosoma cruzi altamente virulenta para o camundongo branco. Folha Clínica Biol São Paulo. 1953:20:191-201.

28. Yang C, Liu Z, Liu K, Yang P. Mechanisms of Ghrelin anti-heart failure: inhibition of Ang II-induced cardiomyocyte apoptosis by down-regulating AT1R expression. PLoS One. 2014;9:e85785.

29. Soriano RN, Nicoli LG, Carnio EC, Branco LG. Exogenous ghrelin attenuates endotoxin fever in rats. Peptides. 2011;32:2372-6.

30. Eid RA, Alkhateeb MA, Eleawa S, Al-Hashem FH, Al-Shraim M, El-Kott AF, et al. Cardioprotective effect of ghrelin against myocardial infarctioninduced left ventricular injury via inhibition of SOCS3 and activation of JAK2/STAT3 signaling. Basic Res Cardiol. 2018;113:13.

31. Soeki T, Kishimoto I, Schwenke DO, Tokudome T, Horio T, Yoshida M, et al. Ghrelin suppresses cardiac sympathetic activity and prevents early left ventricular remodeling in rats with myocardial infarction. Am J Physiol Heart Circ Physiol. 2008;294:H426-32.

32. Yang C, Liu J, Liu K, Du B, Shi K, Ding M, et al. Ghrelin suppresses cardiac fibrosis of post-myocardial infarction heart failure rats by adjusting the activin A-follistatin imbalance. Peptides. 2018:99:27-35.

33. Yuan MJ, Huang H, Tang YH, Wu G, Gu YW, et al. Effects of ghrelin on Cx43 regulation and electrical remodeling after myocardial infarction in rats. Peptides. 2011;32:2357-61. 
34. Brener Z. Therapeutic activity and criterion of cure in mice experimentally infected with Trypanosoma cruzi. Rev Inst Med Trop São Paulo. 1962:4:389-96.

35. Costa CM, da Brazão V, Collins Kuehn C, Rodrigues Oliveira LG, do Prado Júnior JC, Sala MA, et al. Zinc and pregnancy: marked changes on the immune response following zinc therapy for pregnant females challenged with Trypanosoma cruzi. Clin Nutr. 2013;32:592-8.

36. Bryan NS, Grisham MB. Methods to detect nitric oxide and its metabolites in biological samples. Free Radic Biol Med. 2007:43:645-57.

37. de Freitas MRB, da Costa CMB, Pereira LM, do Prado JCJ, Sala MA, Abrahao AAC. The treatment with selenium increases placental parasitismin pregnant Wistar rats infected with the Y strain of Trypanosoma cruzi. Immunobiology. 2018:223:537-43.

38. Camargo MM, Almeida IC, Pereira ME, Ferguson MA, Travassos LR, Gazzinelli RT. Glycosylphosphatidylinositol-anchored mucin-like glycoproteins isolated from Trypanosoma cruzi trypomastigotes initiate the synthesis of proinflammatory cytokines by macrophages. J Immunol. 1997; 158:5890-901

39. Wang JX, Tang W, Shi LP, Wan J, Zhou R, Ni J, et al. Investigation of the immunosuppressive activity of artemether on T-cell activation and proliferation. Br J Pharmacol. 2007;150:652-61.

40. Del Vecchio Filipin M, Brazao V, Santello FH, da Costa CMB, Paula Alonso Toldo M, de Rossetto Morais F, et al. Does Prolactin treatment trigger imunoendocrine alterations during experimental T cruzi infection? Cytokine. 2019;121:154736.

41. da Costa CM, de Freitas MR, Brazao V, dos Santos CD, Sala MA, do Prado Junior JC, et al. Does L-arginine availability during the early pregnancy alters the immune response of Trypanosoma cruzi infected and pregnant Wistar rats? Exp Parasitol. 2014;142:59-66.

42. Basso B. Modulation of immune response in experimental Chagas disease. World J Exp Med. 2013:3:1-10.

43. de Souza W, de Carvalho TM, Barrias ES. Review on Trypanosoma cruzi: host cell interaction. Int J Cell Biol. 2010;2010:295394.

44. Oliveira LRC, Picka MCM, Nicolete VC, Calvi SA, Marcondes-Machado J. Organ tropism during the acute and chronic phases of Trypanosoma cruzi infection in BALB/c mice. JVenom Anim Toxins Incl Trop Dis. 2012;18:34-43.

45. Baatar D, Patel K, Taub DD. The effects of ghrelin on inflammation and the immune system. Mol Cell Endocrinol. 2011;340:44-58.

46. Churm R, Davies JS, Stephens JW, Prior SL. Ghrelin function in human obesity and type 2 diabetes: a concise review. Obes Rev. 2017;18:140-8.

47. Pereira J, da Silva FC, de Moraes-Vieira PMM. The impact of Ghrelin in metabolic diseases: an immune perspective. J Diabetes Res. 2017;2017:4527980.

48. Malafaia G, Talvani A. Nutritional status driving infection by Trypanosoma cruzi: lessons from experimental animals. J Trop Med. 2011;2011:981879.

49. Acevedo GR, Girard MC, Gomez KA. The unsolved jigsaw puzzle of the immune response in Chagas disease. Front Immunol. 2018;9:1929.

50. Nahrevanian $\mathrm{H}$. Involvement of nitric oxide and its up/down stream molecules in the immunity against parasitic infections. Braz J Infect Dis. 2009:13:440-8.

51. Paiva CN, Medei E, Bozza MT. ROS and Trypanosoma cruzi: fuel to infection, poison to the heart. PLoS Pathog. 2018;14:e1006928.

52. Xaus J, Comalada M, Valledor AF, Cardo M, Herrero C, Soler C, et al. Molecular mechanisms involved in macrophage survival, proliferation, activation or apoptosis. Immunobiology. 2001;204:543-50.

53. Poncini CV, Gonzalez-Cappa SM. Dual role of monocyte-derived dendritic cells in Trypanosoma cruzi infection. Eur J Immunol. 2017;47:1936-48.

54. Antunez Ml, Cardoni RL. Trypanosoma cruzi: the expansion of NK, T, and NKT cells in the experimental infection. Exp Parasitol. 2004;106:85-94.

55. Balato A, Unutmaz D, Gaspari AA. Natural killer T cells: an unconventional T-cell subset with diverse effector and regulatory functions. J Invest Dermatol. 2009;129:1628-42.

56. Shirshev SV, Nekrasova IV, Orlova EG, Gorbunova OL. Roles of leptin and ghrelin in the regulation of the phenotype and cytokine production by NK cells from peripheral blood. Dokl Biol Sci. 2016;470:249-52.

57. Martin DL, Weatherly DB, Laucella SA, Cabinian MA, Crim MT, Sullivan S, et al. CD8+ T-Cell responses to Trypanosoma cruzi are highly focused on strain-variant trans-sialidase epitopes. PLoS Pathog. 2006;2:e77.

58. Dos Santos Virgilio F, Pontes C, Dominguez MR, Ersching J, Rodrigues MM, Vasconcelos JR. CD8(+)T cell-mediated immunity during Trypanosoma cruzi infection: a path for vaccine development? Mediators Inflamm. 2014;2014:243786.

59. da Costa TA, Silva MV, Mendes MT, Carvalho-Costa TM, Batista LR, Lages-Silva E, et al. Immunomodulation by Trypanosoma cruzi: toward understanding the association of dendritic cells with infecting $\mathrm{TCl}$ and Tcll populations. J Immunol Res. 2014;2014:962047.

60. Silverio JC, Pereira IR, Cipitelli Mda C, Vinagre NF, Rodrigues MM, Gazzinelli RT, et al. CD8+ T-cells expressing interferon gamma or perforin play antagonistic roles in heart injury in experimental Trypanosoma cruzielicited cardiomyopathy. PLoS Pathog. 2012;8:e1002645.

61. Sikora E. Activation-induced and damage-induced cell death in aging human T cells. Mech Ageing Dev. 2015;151:85-92.

62. Freire-de-Lima $L$, da Fonseca $L M$, da Silva VA, da Costa KM, Morrot $A$, Freire-de-Lima CG, et al. Modulation of cell sialoglycophenotype: a stylish mechanism adopted by Trypanosoma cruzi to ensure its persistence in the infected host. Front Microbiol. 2016;7:698.

63. Leguizamon MS, Mocetti E, Garcia Rivello H, Argibay P, Campetella O. Trans-sialidase from Trypanosoma cruzi induces apoptosis in cells from the immune system in vivo. J Infect Dis. 1999;180:1398-402.

64. Zhang D, Wang W, Zhou D, Chen Y, Han L, Liu Y, et al. Ghrelin inhibits apoptosis induced by palmitate in rat aortic endothelial cells. Med Sci Monit. 2010;16:Br396-403.

65. Lee JH, Kim TJ, Kim JW, Yoon JS, Kim HS, Lee KM. The anti-apoptotic effect of ghrelin on restraint stress-induced thymus atrophy in mice. Immune Netw. 2016;16:242-8.

66. Zhang Y, Ying B, Shi L, Fan H, Yang D, Xu D, et al. Ghrelin inhibit cell apoptosis in pancreatic beta cell line HIT-T15 via mitogen-activated protein kinase/phosphoinositide 3-kinase pathways. Toxicology. 2007;237:194-202.

67. Tostes S Jr, Bertulucci Rocha-Rodrigues D, de Araujo Pereira G, Rodrigues $\checkmark \mathrm{Jr}$. Myocardiocyte apoptosis in heart failure in chronic Chagas disease. Int J Cardiol. 2005;99:233-7.

68. DosReis GA, Lopes MF. The importance of apoptosis for immune regulation in Chagas disease. Mem Inst Oswaldo Cruz. 2009;104(Suppl. 1):259-62.

69. Lieke T, Steeg C, Graefe SE, Fleischer B, Jacobs T. Interaction of natural killer cells with Trypanosoma cruzi-infected fibroblasts. Clin Exp Immunol. 2006;145:357-64.

70. Schoenborn JR, Wilson CB. Regulation of interferon-gamma during innate and adaptive immune responses. Adv Immunol. 2007;96:41-101.

71. Ma X, Yan W, Zheng H, Du Q, Zhang L, Ban Y, et al. Regulation of IL-10 and IL-12 production and function in macrophages and dendritic cells. F1000Res. 2015;4:1465.

72. Yoo JK, Cho JH, Lee SW, Sung YC. IL-12 provides proliferation and survival signals to murine CD4+ T cells through phosphatidylinositol 3-kinase/Akt signaling pathway. J Immunol. 2002;169:3637-43.

73. Vacaflores A, Chapman NM, Harty JT, Richer MJ, Houtman JC. Exposure of human CD4 T cells to IL-12 results in enhanced TCR-induced cytokine production, altered TCR signaling, and increased oxidative metabolism. PLoS One. 2016;11:e0157175.

74. Tanaka T, Narazaki M, Kishimoto T. IL-6 in inflammation, immunity, and disease. Cold Spring Harb Perspect Biol. 2014;6:a016295.

75. Li B, Jones LL, Geiger TL. IL-6 promotes T cell proliferation and expansion under inflammatory conditions in association with low-level RORgammat expression. J Immunol. 2018;201:2934-46.

76. Van Epps HL. IL-6 drives T cell proliferation. J Exp Med. 2006;203:1387.

77. Cardillo F, de Pinho RT, Antas PR, Mengel J. Immunity and immune modulation in Trypanosoma cruzi infection. Pathog Dis. 2015;73:ftv082.

78. Sun J, Tarleton RL. Predominance of CD8+T lymphocytes in the inflammatory lesions of mice with acute Trypanosoma cruzi infection. Am J Trop Med Hyg. 1993;48:161-9.

79. Gomes JA, Bahia-Oliveira LM, Rocha MO, Martins-Filho OA, Gazzinelli G, Correa-Oliveira R. Evidence that development of severe cardiomyopathy in human Chagas disease is due to a Th1-specific immune response. Infect Immun. 2003;71:1185-93.

80. Reis MM, Higuchi Mde L, Benvenuti LA, Aiello VD, Gutierrez PS, Bellotti $G$, et al. An in situ quantitative immunohistochemical study of cytokines and IL-2R+ in chronic human chagasic myocarditis: correlation with the presence of myocardial Trypanosoma cruzi antigens. Clin Immunol Immunopathol. 1997;83:165-72. 
81. Khatib MN, Simkhada P, Gode D. Cardioprotective effects of ghrelin in heart failure: from gut to heart. Heart Views. 2014;15:74-6.

82. Mitacchione G, Powers JC, Grifoni G, Woitek F, Lam A, Ly L, et al. The gut hormone ghrelin partially reverses energy substrate metabolic alterations in the failing heart. Circ Heart Fail. 2014;7:643-51.

\section{Publisher's Note}

Springer Nature remains neutral with regard to jurisdictional claims in published maps and institutional affiliations.
Ready to submit your research? Choose BMC and benefit from:

- fast, convenient online submission

- thorough peer review by experienced researchers in your field

- rapid publication on acceptance

- support for research data, including large and complex data types

- gold Open Access which fosters wider collaboration and increased citations

- maximum visibility for your research: over 100M website views per year

At BMC, research is always in progress.

Learn more biomedcentral.com/submissions 